Library Management, 2007, Vol. 28, No. 6/7, p.366-378.

ISSN:0143-5124

doi: $10.1108 / 01435120710774503$

http://www.emeraldinsight.com/index.htm?PHPSESSID=oib9rnl8j0vtc3ua0de88bp641

http://www.emeraldinsight.com/journals.htm?issn=0143-5124

http://www.emeraldinsight.com/journals.htm?issn=0143-

$5124 \&$ volume $=28 \&$ issue $=6 \&$ articleid $=1617033 \&$ show $=$ abstract

(C) 2007 Emerald Group Publishing Limited

\title{
Assessing trends to cultivate new thinking in academic libraries
}

\section{Sally A. Rogers}

The Ohio State University Libraries, Columbus, Ohio, USA

\begin{abstract}
Purpose - The purpose of this paper is to present an organized view of current trends affecting academic libraries that one research library developed to encourage new thinking; this view could assist others seeking to help their organizations think differently about the future of information access and management.

Design/methodology/approach - One strategy for identifying important trends using a small number of key resources is highlighted in the paper. A snapshot of the many trends affecting academic libraries is categorized to show interrelationships and to provide specific examples along with a general overview. Included is a brief description of how the snapshot was used by one library. Implications for the future and perspectives on the value of cultivating new thinking are presented in the conclusion.

Findings - The paper finds that rapid and far-reaching change is challenging libraries to think very differently, to act much more quickly, and to set trends rather than merely react to them. Assessing trends can help libraries foster organizational change through exposure to new ideas and see where new partnerships and areas of expertise must be developed to meet new needs.

Practical implications - The snapshot became the basis for two library-wide events at Ohio State that better positioned attendees to inform and to accommodate decisions about service priorities, personnel and budget requests.

Originality/value - This paper organizes many diverse trends into a general overview to make interrelationships and implications more understandable to those unlikely to develop such a view on their own for example: university personnel outside the library, middle managers and those they supervise within the library, students of library and information management.

Keywords Academic libraries, Change management, Information management

Paper type Viewpoint
\end{abstract}

\section{Introduction}

Those in leadership positions in higher education and in academic libraries face a significant challenge as they try to envision the future with some degree of accuracy in order to make good decisions about service priorities, resource allocations, and organizational structures. Visibility into the future is so limited that it is a challenge to predict what will be expected of these organizations even two or three years from now. If visibility is limited for those in upper level leadership positions, it could be non-existent for those at other levels in their organizations if regular exposure to new perspectives and ideas has not been a priority.

The following article presents a view of current trends in academic libraries that was developed at The Ohio State University Libraries (OSUL) to encourage new thinking to inform decisions about future directions. Because it was a challenge to show in some coherent fashion how the many key trends affecting academic libraries relate to one another as the basis for a 
library-wide discussion, the resulting view is being shared in the hope that it might assist others looking for meaningful ways to Assessing trends help their organizations think about the future.

\section{Related resources}

Just as trends abound, so does the information about them; that is part of the problem how to keep up with reading it and how to tie it all together into something that makes sense and is usable as a basis for decision making. Many strategies are possible. One is to track a few carefully selected resources that one is confident will provide or lead to information on the most important trends. A few such resources that were used to create the snapshot of trends at OSU are cited here as examples.

Tracking current trends requires using resources that report information while it is indeed current. It is helpful to identify others who have demonstrated an ability to assess trends and to set appropriate directions in the arenas that impact academic libraries in order to benefit from their thinking. The semi-annual meetings of the Coalition for Networked Information (CM) Task Force offer both very current information and the perspectives of CNI's executive director Clifford Lynch, whose knowledgeable insights are well worth hearing on a regular basis. His "meeting roadmap" and the project briefings for the spring and fall Task Force meetings and are posted on the CNI web site (CNI, n.d.) only a few weeks ahead of time, ensuring their currency. The CNI-ANNOUNCE electronic forum gives subscribers invaluable updates on key developments and reports as well as announcing various conference opportunities throughout the year. An archive of the forum is available.

D-Lib Magazine has as its goal "timely and efficient information exchange for the digital library community" (D-Lib, n.d.). Its 11 (electronic only) issues per year include articles on current topics, as well as current awareness and event links. Some articles are solicited, and many are written by leaders of key initiatives in the field.

OCLC also offers timely information on current issues through its newsletter, now called NextSpace, and the OCLC Symposium held at semi-annual conferences of the American Library Association (ALA). Symposium presentations, such as the one held in January 2006 entitled "Rebranding an Industry: Extreme Makeover," are available on the OCLC web site (OCLC, n.d.). OCLC offers podcasts, RSS feeds, and weblogs, such as the one by Lorcan Dempsey, their chief strategist and vice president for Research, who regularly shares visionary thinking through his blog and many other venues. Several significant reports on the current information environment and perceptions of actual and potential library users have been issued by OCLC in the past few years. Cathy De Rosa, vice president of Marketing and Library Services for OCLC, was a principal contributor to these reports; and she has given many excellent presentations sharing important perspectives on their contents (De Rosa, 2004, 2005).

EDUCAUSE (n.d.) offers information about technology trends in higher education through its conferences and publications, such as EDUCAUSE Review and EDUCAUSE Quarterly, both of which are available on the organization's web site. The May/June 2006 issue of EDUCAUSE Review includes a message from the executive team indicating the organization is expanding its focus to look at campus issues and "grand challenges," not just IT issues (Hawkins et al, 2006).

There are many other resources that are important sources of information on the latest trends affecting academic libraries. One could cite, for example, The Chronicle of Higher Education, The New York Times, First Monday, Wired Magazine, Information Today, conference proceedings and webcasts on current topics, reports of recently funded research projects and the 
outcomes of that research. Whatever sources are used, the critical factor is to look beyond the library to see it within the context of what is happening in the academy, in industry, in government, and in society.

For those who regularly read the above-mentioned sources, the snapshot of current trends that follows will not be surprising. Its intended value lies in the gathering and organization of trends into something that hopefully makes sense to those who might not be consulting such resources routinely or who might not have had the time to analyze and to synthesize the information. These individuals might include university personnel outside the library, middle managers and those they supervise within the library, and students of library and information management.

\section{Snapshot of trends}

New models for content management

A trend introduced in the past several years has been new models for content management; for example, institutional and other repositories that use open source platforms like DSpace (n.d.) and Fedora (n.d.); course management systems that now also can serve as digital content repositories; and systems that support the creation and/or management of peer reviewed e-journals such as bepress (n.d.) and the open source DPubS (n.d.) software being developed by the Cornell University Libraries in collaboration with the Pennsylvania State University Libraries and Press. The impetus has been the recognition that digital content constitutes a valuable asset that should be managed better than it has been. OSU is exploring the relationship of its DSpace repository (the OSU Knowledge Bank) to the statewide Fedora repository (the Digital Resource Commons) being built by the OhioLINK (n.d.) consortium and the learning object repository that is a part of Desire2Learn (Desire2Learn.com, n.d.), the newly implemented course management system (called Carmen at OSU).

This trend offers new opportunities for libraries, both in terms of content production and content management, because much of the content is outside the realm of what libraries traditionally collect, organize, and deliver. Because libraries are investing their resources in producing and gathering content in addition to purchasing it, the development of collection policies for digital and repository initiatives would seem advisable. The OSU Libraries' Collections Advisory Council has been consulted about proposed digital projects, but no formal collections policy for digital initiatives has been written.

New models for the creation and dissemination of scholarship should help to advance the movement to create change in scholarly communication. Libraries have supported this movement and the new open access journals that have resulted from it. They have encouraged faculty to take a stand against exorbitant journal price increases in their disciplines. But many challenges remain in this arena.

Marianne Gaunt, a speaker at the 2005 American Library Association (ALA) annual conference, questioned whether the journal creation process of peer review, editorial services, distribution, and archiving should be unbundled in a new business model. Dan Greenstein, who spoke at the same session, noted that the most important aspect is the identification of quality. If a new model can be designed to do that, the current system of journal publishing should be changeable.

New levels of granularity 
Management of content at finer levels of granularity is possible with some of the new options described above, and the current trend is to focus on the content itself, not on the containers in which it comes. A thought-provoking report on this topic was issued by OCLC Online Computer Library Center, in 2004. It states:

Content is no longer format-dependent and users are not dependent on traditional distribution channels for access to content. This is true both in the realms of scholarly communication and popular materials. For libraries and content sellers, this means the processes of acquisition, organization and delivery of content need to change to accommodate the expectations of our communities (OCLC Online Computer Library Center, 2004, p. 2).

Nancy Davenport gave an example of this trend when she spoke at the 2005 ALA annual conference. She mentioned that a couple of academic libraries cancelled subscriptions to ancillary titles and put half of the money they saved aside to buy articles from those titles as needed. They found that they needed to spend only about half of what they put aside.

\section{New roles and opportunities}

The new models for content management also offer end-users in various communities the options of submitting content and metadata themselves and of deciding what content to include in their collections. If end-users enthusiastically embraced these new models, one might question whether there will be a significant role for libraries in managing the non-traditional content. But the trend to date has been for end-users to resist taking time away from their primary scholarly pursuits such as research to digitize, to submit, and to describe their output for the new repositories. However, the fact that the option exists for the end-user to do functions similar to those that libraries have done as stewards of print and electronic resources creates the following opportunities for libraries:

- To play a new role as facilitators in making end-user participation as easy as possible.

- To partner with end-users to manage their content (by offering a digitization service or a metadata service, for example).

- To advise on the development of tools that simplify the process of content creation and dissemination for the end-user, recognizing that tools and applications have become a primary technology development focus (whereas hardware was the focus in the past).

One motivator for faculty to be interested in institutional repositories is the emphasis that federal agencies have started to place on preservation of digital content created with their grant funding. Faculty are looking to the library for assistance in addressing this preservation aspect when preparing grant proposals.

In general, attention to digital preservation is increasing in conjunction with heightened awareness of both the value and the vulnerability of digital content. Mechanisms are needed to ensure authenticity and integrity of content not only when it is first created, but also over time. Libraries, as creators, sponsors, and stewards of digital content, must be thinking at the outset how they will migrate and preserve it on an ongoing basis. These are areas that must be given more attention, particularly given the rising number of computer security threats. Cornell University Library offers a workshop on digital preservation management. The workshop web 
site includes a tutorial (Cornell University Library, n.d.) containing an informative timeline that presents milestones in digital technology and preservation, including major preservation initiatives that are currently underway.

New scale

Another recent trend in the area of content management is mass digitization on a scale and at a pace that previously has seemed unachievable. Google's announcement in fall 2004 of plans to digitize all or part of the collections of five libraries for their Google Print project (now called Google Book Search) garnered considerable interest as well as concern about possible copyright violations. Regardless of the outcome of this particular initiative, or others such as the digital content archive being built by the Open Content Alliance (n.d.), what is significant is that mass digitization on the scale proposed by Google is now plausible. Technological advances have allowed scanning to be done more quickly and with less human intervention. Digital storage costs have declined significantly. And perhaps most importantly, there are players willing to take the risks and to invest to make it happen. These convergence factors have set the stage for new opportunities and partnerships for libraries.

\section{New access options}

In parallel to the attempts to take advantage of the wealth of information in library print collections through mass digitization, there are efforts underway to leverage the rich store of library-created metadata through harvesting by the major internet search engines. For example, Google and Yahoo! have harvested selected fields from records in OCLC's WorldCat database so that library resources can be retrieved in response to a general internet search. Such responses are flagged as "find in a library." OCLC provides institutions with statistics on the amount of web traffic going to library resources from this Open WorldCat program. The statistics for OSU show an average of 1,022 public (i.e. unauthenticated) accesses of the catalog, library information, or Ask-a-Librarian options each month from January to December 2005. Internet users who otherwise might not have found OSU's library resources are being led to those resources through Open WorldCat.

The role of the local library catalog relative to the various other new access options remains a question, however. Putting library catalog records on the open internet has led people to start thinking differently about local OPACs, including questioning whether they will be needed in the future. Dissatisfied with current OPAC functionality, some libraries have purchased new search interfaces that work in conjunction with, but do not replace, their existing library catalogs. For example, North Carolina State University (NSCU Libraries, n.d.) implemented Endeca's search technology in January 2006. AquaBrowser (n.d.) is another interface option offering advanced searching capabilities. In addition, University of Rochester's River Campus Libraries received a grant from the Andrew W. Mellon Foundation in April 2006 to explore requirements for a new open-source online system known as extensible Catalog (XC) (Dickman, 2006). New interfaces can make it much easier for users to take advantage of the richness of the MARC metadata in the library catalog to refine their searches - but the users still have to know that the catalog exists and where to find it in order to use the new functionality.

New access options also are raising questions related to management of the local catalog. For example, library personnel working on an oral history project for OSU's Knowledge Bank created links from related catalog records to the content added to the repository. They also 
requested system changes when they identified problems with the way the metadata displayed when searching for the oral histories in the Knowledge Bank. It seemed perfectly natural to make these access improvements because library -personnel were conducting the project. However, had a non-library community been responsible for inputting their own content and metadata, it is quite possible that the library would not have known of the display problem or of the relationships of repository content to items in the library catalog.

The control that libraries typically have maintained over their catalogs may be an unrealistic goal for the repository model that is intended to support an expanded universe of contributors. Further, given the increasing number of access options that are not controlled by the library, what is the relative value of continuing to exert high levels of control over what goes into the catalog? Also, does it make sense to try to make the non-catalog options search and display like the catalog - or are they different models with different purposes? Libraries cannot effectively answer these questions through introspection. They must engage in ongoing dialogues with those they wish to serve.

\section{New design principles for libraries}

Scott Bennett, a library space consultant, has written and lectured convincingly about the need for library spaces to be designed to support learning more directly (Bennett, 2003). For example, users want more areas to study and to work in groups. The theme of the July /August 2005 issue of EDUCAUSE Review is learning space design. One of the articles summarizes characteristics of the well-designed classroom of the future as follows (Long and Ehrmann, 2005):

- designed for people, not for ephemeral technologies;

- optimized for certain learning activities; not just stuffed with technology;

- enables technologies to be brought to the space, rather than having them built into the space;

- allows invisible technology and flexible use;

- emphasizes soft spaces;

- useful across the 24-hour day; and

- "zoned " for sound and activity.

If academic libraries are to support learning more directly, then perhaps the well-designed library of the future should have these same characteristics.

The article also describes a fascinating vision of what the authors call "situated computing" where instructions are embedded in the physical space to tell devices within that space how they should be configured. For example, a faculty member could use his or her course schedule to create an event profile for a particular class session, indicating any technology support needs. When the faculty member enters the classroom for the session, the building network reads a radio frequency identification (RFID) tag on his or her ID, retrieves the event profile, and activates the appropriate support devices according to the preferences specified in the profile. When students enter the classroom, their IDs can register their presence with the network and information for the class can be transferred to their preferred workspaces, which might be handheld devices. Those trying to envision what academic library spaces should look like in the future might find it helpful to keep this type of visionary thinking about classrooms in mind. 
New mobility

It is obvious from simple observation that the use of mobile communications and computing devices is increasing. A logical assumption is that this trend can be expected to have a larger impact on libraries in the future. An article in the May/June 2005 EDUCA USE Review on "Enabling mobile learning" quotes Penny Wilson of Macromedia who has described mobile wireless devices as "tools of mass disruption" because of the innovations in learning technologies that they are expected to spark (Wagner, 2005).

In July 2005, it was announced that a new URL suffix -.mobi - had been defined for use by sites that specifically format their content for display on the small screens of cell phones and other internet-capable handheld devices. The initial domain name registration opened in May 2006. Mobile phone companies asked for the new domain name and are encouraging its use. Presumably, the more internet content that is available for cell phones and the easier it is to access, the more interest there will be in phones with greater functionality, allowing the companies to expand their markets (Reardon, 2006).

Libraries have been offering online reference for some time, but now they are experimenting with additional and possibly more convenient ways that this could be done. Instant messaging (IM) is one popular option, and Short Message Service (SMS) could be another. A university library in Australia is offering an "SMS a Query" service to allow librarians to receive short text messages of up to 160 characters any time from anywhere using cell phones (OCLC Online Computer Library Center, 2006). One company, Altarama, also in Australia, markets software to support delivery of reference services via SMS. In the USA, the library at Southeastern Louisiana University offers a text message reference service (Hines, 2005).

\section{New influences and expectations}

Gaming also is going mobile. A 2005 issue of the OCLC Newsletter compared "gamers" and "boomers" and talked about implications for libraries. One article quoted Marc Prensky on the impact of gaming:

Today's average college grads have spent less than 5,000 hours of their lives reading, but over 10,000 hours playing video games. Today's students think and process information fundamentally differently from their predecessors (Beck, 2005).

The article also notes that the author, Beck, found that web sites with a game component capture and hold people's attention better than any other. Based on a survey of more than 2,000 professionals and hundreds of interviews, Beck is convinced that video games will have a significant impact on our entire culture.

Blogs, wikis, podcasting and the like are having an impact as well. The March/April 2006 issue of EDUCAUSEReview includes an in-depth description of the proliferation of Web 2.0 services and tools that support social networking. The article also explores Assessing trends the pedagogical implications of Web 2.0 (Alexander. 2006). For example, these technologies can enable student group learning as well as collaborative research by faculty; and lectures available as podcasts from the class wiki can make the learning process more mobile. But many wikis and blogs are not scholarly enterprises. They offer easy ways to self publish on the web and, as a 
result, the amount of amateur digital content that is available is growing. Svoboda (2006) notes in the May 2006 IEEE Spectrum Online:

As the first-ever major reference work with a democratic premise - that anyone can contribute an article or edit an entry - Wikipedia has generated shared scholarly efforts to rival those of any literary or philosophical movement in history. Its signature strength, however, is also its greatest vulnerability. Usergenerated articles are often inaccurate or irrelevant, and vandals ... are a constant threat.

In fact even Wikipedia's founder, Jimmy Wales, warns college students not to use Wikipedia for class projects or serious research (The Chronicle of Higher Education, 2006).

Joan Frye Williams, a librarian and consultant on information technology planning, spoke at the 2005 ALA Annual Conference about the surprising level of trust that people are placing in peer-supplied information. She noted that the library has lost its premier position as a trusted source. OCLC's 2006 report (De Rosa et al, 2006, pp. 6-4) on college students' perceptions supports this view:

College students trust information they get from libraries, and they trust the information they get from search engines. The survey revealed that they trust them almost equally, which suggests that libraries have no monopoly on the provision of information.

With exposure to many different options for information gathering, users are developing expectations for accessing library resources that are shaped by the general internet. In the past, even if it was difficult or time-consuming to access information provided by the library, users would do it because they had no other choice. Now, in the minds of many, they do have choices; and they are choosing ease of use and convenience even when a somewhat more difficult option would yield better results. Therefore, in order to make sure that valuable content and services are used, libraries need to give as much attention to convenience and ease of use as to ensuring that resources are of high quality.

Where students are concerned, the need to teach them how to learn, not just how to use library resources, is probably as great as it has ever been. However, librarians working toward this goal need to be sure to teach techniques that really will be used. If the pathways to the library's riches are too convoluted, more energy should be focused on building simpler pathways than on giving better navigation instructions. The implication is that libraries should be interacting more with those that they want to serve in a way that will enhance their understanding of current and future user needs.

New partnerships

One way for libraries to assess how well they are supporting learning and research and what useful new services they might provide is to work even more closely with academic departments. Collection development librarians traditionally have interacted with teaching faculty to address the collections needs of academic programs. Initiatives such as institutional repositories call for new partnerships centered on creation, delivery, and preservation of digital content and metadata. These areas also represent new service opportunities for the library. For example, James Mullins, dean of the Purdue University Libraries, is encouraging the Libraries' faculty to collaborate on interdisciplinary sponsored research initiatives with colleagues in colleges and schools throughout the university (Purdue University Libraries, 2005). Through extensive conversations with campus faculty, Mullins has found that the researchers have many - 
needs that can be met by the type of expertise offered by librarians, such as the ability to organize and manage large data sets. Several sponsored research proposals naming Purdue librarians as part of the research team have been funded (Mullins and Brandt, 2006).

\section{New organizations}

The summer 2004 issue of Library Trends is devoted to organizational development as practiced in libraries. The issue editors, Denise Stephens and Keith Russell, provide an extensive review of the literature on organizational development, change, and leadership in several disciplines. In their article (Stephens and Russell, 2004, p. 240), they note:

\footnotetext{
The library community is well aware of the impacts of rapidly changing information technology, evolving user expectations and information-seeking behaviors, and changes in information publishing and dissemination. It is unclear, however, whether awareness of these driving environmental issues equals understanding and whether the knowledge of these issues is applied to planning and implementation of change in library organizations.
}

One of the changes that is taking place is for student assistants to be given different types of responsibilities. Libraries such as Georgia Tech have found that users respond very well to being helped by their peers. They are using student assistants as an interface for student users of their facilities and services, particularly where computer and multimedia support are concerned. At OSU, an innovative Peer Library Tutor program was implemented in 2005 to train students to assist their peers with research and use of library resources. The pilot program, developed by Katharine Webb, was highly successful and resulted in plans for expansion to other areas of the library in 2006.

Another trend is for academic libraries to define new positions to manage scholarly communication issues. For example, OSU has an experimental Rights Management Coordinator position that is responsible for providing leadership in this area. Redefining responsibilities for existing personnel is a trend as well. At OSU, some members of Technical Services now have a role in seeking copyright permissions for faculty and in promoting rights awareness on campus. Others are assisting with the development of a campus-wide expertise system called OSU:Pro and are working with campus units on submission of content to the Knowledge Bank.

Because the information environment has changed significantly, traditional library organizational structures do not necessarily fit the work that needs to be done now. At OSU, there has been a recent shift to cross-disciplinary management of common public service functions (e.g., circulation, reference, management of the collection) by a team of coordinators reporting to an assistant director. Previously, all functions within a discipline were managed by the subject matter expert. The goal has been to allow subject experts to devote less time to operational issues and more time to new responsibilities requiring their scholarly expertise.

\section{Using the trends snapshot}

The foregoing snapshot of trends affecting academic libraries was the focus of two open meetings to which all OSU library personnel were invited. The first event was an overview presentation (by the author) that grouped more than 20 individual trends into four categories, namely: 
(1) content management;

(2) changing uses and users of libraries;

(3) outreach, teaching, and learning; and

(4) changing personnel patterns.

The purpose of the overview was to provide some structure and a sense of relationship among the various trends that might not be readily apparent. It also connected the trends to activities underway at OSU or at other universities to ground them in reality while also looking to the future.

The second event was a half-day in-service session away from the library. Attendees were divided randomly into groups and asked to rate seven trends (some from each major category) according to the impact and effort involved with taking action. Facilitated discussion of the outcome followed, with attendees sharing the reasoning behind their ratings. Then each group brainstormed one of its trends to generate ideas on specific actions the library should take in response.

The trends events gave personnel throughout the OSU Libraries an opportunity to think and to interact with one another in new ways. The overview established some common ground and a current context. The group exercises encouraged different perspectives on possible actions and priorities. Together, the events put attendees in a better position to inform and to accommodate subsequent decisions about service priorities, positions to be filled, and budget requests.

\section{Conclusion}

Rapid and far-reaching change has become the norm for the environment in which academic libraries operate, necessitating that library personnel think very differently and act much more quickly. These challenges are significant, especially for large research libraries where the size of the organization often impedes nimbleness in responding to current trends. Indeed, a big part of the struggle is for libraries to be proactive and trend setting rather than merely reactive to trends imposed upon them. This cannot be done without cultivating and maintaining a world view that looks well beyond the library.

Whether the focus is content, services, outreach, or personnel, libraries cannot succeed by working in isolation. They must evaluate, obtain, and support products from more and more vendors whose primary clients are not libraries; participate in development and support of technology solutions with members of open-source communities; partner with other campus units to deliver coherent enterprise-wide information services through architectures that simplify discovery and navigation for an increasingly mobile population; develop new relationships with knowledge seekers to understand and meet their changing needs; consult experts in other professions for guidance on design of facilities and services; recognize and manage the influence of new government policies and legislation; and collaborate creatively to bring needed new skill sets into their organizations.

All of this must be done with the expectation that budgets for libraries, universities, and their consortia are likely to be stable (at best) or decreasing. The financial challenges are significant. To compete successfully for limited funds, libraries must demonstrate excellence and value in a way that is recognized, not only by those distributing the funds, but also by those who are fellow competitors for it. There is work to be done in this arena. The value of what libraries offer is not as clearly recognizable as it once was because the uniqueness associated with library 
offerings has diminished.

The future does not hinge on our processes or on our technologies, but on our ability to build new supportive relationships for libraries. This may require establishing many individual relationships between library and non-library personnel to build mutual understandings of needs and expertise to serve as a foundation for new organizational relationships. It will also require that the library personnel bring something seen as important and needed to the table.

Monitoring current trends is essential to help libraries identify opportunities to build new relationships and to strengthen and grow their expertise accordingly. Involving the entire organization in this process is beneficial because it solicits the widest range of perspectives and also fosters essential change through exposure to new ideas. Examining current trends gives the future some shape, even in the face of great uncertainty, and allows people to envision something of value in what lies ahead rather than seeing only what they must leave behind.

\section{References}

Alexander, B. (2006), "Web 2.0: a new wave of innovation for teaching and learning?", EDUCAUSEReview, Vol. 412, March/April, pp. 33-44, available at: $\underline{w w w . e d u c a u s e . e d u / i r / l i b r a r y / p d f / e r m 0621 . p d f ~(a c c e s s e d ~ J u l y ~ 9, ~}$ 2006).

AquaBrowser (n.d.), "AquaBrowser Library", available at: www.aquabrowser.com/ (accessed January 25, 2007).

Beck, J. (2005), "Staying in the game!", OCLC Newsletter, 267, January/February/March, p. 9, available at: www.oclc.org/news/publications/newsletters/oclc/2005/267/downloads/stayinginthegame.pdf (accessed August 4, 2006).

Bennett, S. (2003), Libraries Designed for Learning, Council on Library and Information Resources, Washington,

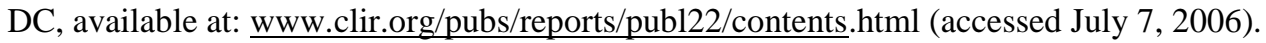

bepress (n.d.), "The Berkeley Electronic Press"TM", available at: www.bepress.com/index.html (accessed January 25 , 2007).

(The) Chronicle of Higher Education (2006), "The Wired Campus: Wikipedia founder discourages academic use of his creation", June 12, available at: http://chronicle.com/wiredcampus/article/1328/wikipedia-founderdiscourages-academic-use-of-his-creation (accessed January 25, 2007).

CNI (n.d.), "Coalition for Networked Information", available at: www.cni.org (accessed July 28, 2006).

Cornell University Library (n.d.), "Timeline: digital technology and preservation", available at: wwwJibraiyxomell.edu/iris/1iitorial/dprn/rimeline/index.html (accessed January 25,2007).

De Rosa, C, Dempsey, L. and Wilson, A. (2004), The 2003 OCLC Environmental Scan: Pattern Recognition, OCLC, Dublin, OH, available at: www.oclc.org/reports/escan/default.htm (accessed July 29, 2006).

De Rosa, C, Cantrell, J., Hawk, J. and Wilson, A. (2006), College Students' Perceptions of Libraries and Information Resources, OCLC Online Computer Library Center, Dublin, $\mathrm{OH}$, available at: www.oclc.org/reports/perceptionscollege.htm (accessed July 29, 2006).

De Rosa, C, Cantrell, J., Cellentani, D., Hawk, J., Jenkins, L. and Wilson, A. (2005), Perceptions of Libraries and Information Resources, OCLC, Dublin, OH, available at: www.oclc.org/ reports/2005perceptions.htm (accessed July 29, 2006).

Desire2Learn.com (n.d.), "Desire2Learn innovative learning technology", available at: www. desire21earn.com/ (accessed January 25, 2007). 
Dickman, S. (2006), "Mellon grant funds planning analysis for future online services", University of Rochester News, April 14, available at: $\underline{w w w}$.rochester.edu/news/show.phpPid = 2518 (accessed January 25, 2007).

D-Lib (n.d.), "About D-Lib Magazine", available at: www.dlib.org/about.html (accessed July 28, 2006).

DPubS (n.d.), "DPubS Digital Publishing System", available at: http://dpubs.org/ (accessed January 25, 2007).

DSpace (n.d.), "DSPACE", available at: www.dspace.org/ (accessed January 25, 2007).

EDUCAUSE (n.d.), .),"Welcome to EDUCAUSE", available at: www.educause.edu (accessed July28, 2006).

Fedora (n.d.), "fedora", available at: www.fedora.info/ (accessed January 25, 2007).

Hawkins, B.L., Golden, C, Luker, M.A., Barone, C.A., Katz, R.N. and Oblinger, D.G. (2006), "A message from the EDUCAUSE executive team", EDUCAUSE Review, Vol. 4 No. 3, May/June, p. 4, available at: www.educause.edu/apps/er/erm06/erm06312.asp (accessed July 7, 2006).

Hines, S. (2005), "Text messaging/SMS reference services", Infolssues, November, available at: www.lib.umt.edu/services/infoissues/archive/nov2005.htm (accessed July 9, 2006).

Long, P.D. and Ehrmann, S.C. (2005), "Future of the learning space: breaking out of the box", EDUCAUSE Review, Vol. 40 No. 4, July/August, pp. 42-58, available at: www.educause. edu/ir/library/pdf/erm0542.pdf (accessed July 7, 2006).

Mullins, J.L. and Brandt, D.S. (2006), "Building an Interdisciplinary Research Program", videotape of presentation March 30, Ohio State University Libraries, Columbus, OH, available http://hdl.handle.net/1811/6122 (accessed July 9, 2006).

NCSU Libraries (n.d.), "Endeca at the NCSU Libraries", available at: www.lib.ncsu.edu/endeca/ (accessed January $25,2007)$.

OCLC (n.d.), "OCLC Online Computer Library Center", available at: www.oclc.org (accessed July 28, 2006).

OCLC Online Computer Library Center (2004), 2004 Information Format Trends: Content, Not Containers, OCLC, Dublin, OH, available at: http://www5.oclc.org/downloads/community/2004infotrends_content.pdf (accessed July 28, 2006).

OCLC Online Computer Library Center (2006), "Send a librarian an SMS", OCLC Newsletter, January/February/March, p. 12, available at: www.oclc.org/news/publications/newsletters/ oclc/2005/267/downloads/n267.pdf (accessed July 9, 2006).

OhioLINK (n.d.), "Ohio Library and Information Network", available at: www.ohiolink.edu/(accessed January 25, 2007).

Open Content Alliance (n.d.), "Open Content Alliance", available at: $\underline{\text { www.opencontentalliance. }}$ org/ (accessed July 7, 2006).

Purdue University Libraries (2005), "Dean of libraries: profile", available at: www.lib.purdue.edu/ admin/deansbio.html (accessed January 25, 2007).

Reardon, M. (2006), "'Dot-mobi' domain for mobile devices hits the web", CNETNews.com, May 23, available at: http://news.com.com/Dot-mobi + domain + for + mobile + devices +hits + the+ Web/21001039_3-6075779.html (accessed January 25, 2007). 
Stephens, D. and Russell, K. (2004), "Organizational development, leadership, change, and the future of libraries", Library Trends, Vol. 53 No. 1, Summer, pp. 238-57.

Svoboda, E. (2006), "One-click content, no guarantees", IEEE Spectrum Online, May, available at: www.spectrum.ieee.org/may06/3412/2 (accessed July 29, 2006).

Wagner, E.D. (2005), "Enabling mobile learning", EDUCAUSE Review, Vol. 40, May/June, pp. 41-52, available at: www.educause.edu/ir/library/pdf/erm0532.pdf (accessed July 7, 2006).

\section{Further reading}

Google (2004), "Google checks out library books", available at: www.google.com/press/pressrel/print_library.html (accessed July 7, 2006).

\section{Corresponding author}

Sally A. Rogers 